\title{
DIREITO DE FAMÍLIA E FLUIDEZ NORMATIVA NO SUPREMO TRIBUNAL FEDERAL
}

\section{FAMILY LAW AND NORMATIVE FLUIDITY AT THE BRAZILIAN SUPREME FEDERAL COURT}

\author{
Rafael de Sampaio Cavichioli \\ Universidade Federal do Paraná - UFPR - (Curitiba, PR, Brasil) \\ José Antônio Peres Gediel \\ Universidade Federal do Paraná - UFPR - (Curitiba, PR, Brasil) \\ Recebimento: 9 set. 2018 \\ Aceitação: 29 out. 2018
}

\begin{abstract}
Como citar este artigo / How to cite this article (informe a data atual de acesso / inform the current date of access):
CAVICHIOLI, Rafael de Sampaio; GEDIEL, José Antônio Peres. Direito de família e fluidez normativa no Supremo Tribunal Federal. Revista da Faculdade de Direito UFPR, Curitiba, PR, Brasil, v. 63, n. 3, p. 233-259, set./dez. 2018. ISSN 2236-7284. Disponível em: <https://revistas.ufpr.br/direito/article/view/61437>. Acesso em: 22 dez. 2018. DOI: http://dx.doi.org/10.5380/rfdufpr.v63i3.61437.
\end{abstract}

\section{RESUMO}

Este artigo identifica as diferentes concepções que embasam a regulação jurídica da família, no Brasil, especialmente da paternidade e da maternidade. A primeira concepção corresponde ao modelo fixado pelo Código Civil de 1916. A segunda decorre das alterações promovidas pela Constituição da República de 1988, reforçadas pela leitura do denominado Direito Civil-Constitucional. Esta última concepção é problematizada pela análise de acórdão do Supremo Tribunal Federal que define critério para estabelecimento da filiação e da paternidade.

\section{PALAVRAS-CHAVE}

Direito de Família. Paternidade. Maternidade. Hermenêutica jurídica.

\begin{abstract}
This paper identifies different conceptions that support the family-law framework in Brazil, especially paternity and maternity. The first conception corresponds to the model provided by the 1916 Civil Code. The second takes place in the changes promoted by the 1988 Brazilian Constitution, reinforced by a reading of the so-called Civil-Constitutional Law. The latter is problematized through the analysis of a Brazilian Supreme Federal Court's ruling that defines criteria for the establishment of parentage and paternity.
\end{abstract}

\section{KEYWORDS}

Family Law. Paternity. Maternity. Legal hermeneutics. 


\section{INTRODUÇÃO}

O parâmetro para determinar a paternidade ou a maternidade para o Direito de Família brasileiro, no regime do Código Civil de 1916, decorria do fato biológico da procriação. A relação jurídica entre pais e filhos não era pautada por qualquer elemento afetivo, razão por que era caracterizada pela objetividade.

Outra face dessa objetividade expressava-se pelo patrimonialismo, pois as normas que definiam o contorno jurídico da relação entre pais e filhos dedicavam-se, principalmente, a disciplinar aspectos patrimoniais. Por fim, como a mulher casada era incapaz e como a administração do patrimônio dos filhos menores era atribuída quase exclusivamente ao pai, as relações jurídicas familiares eram caracterizadas pelo patriarcado.

A Constituição de 1988 alterou essas características, regulou amplamente a família e estabeleceu uma série de princípios e postulados norteadores do Direito de Família, propiciando a construção da denominada metodologia civil-constitucional, que, por sua vez, passou a sustentar a necessidade de o Direito Civil ser interpretado com base nos parâmetros normativos constitucionais. Essa metodologia, no campo da regulação jurídica da paternidade e da maternidade, contribuiu para formular propostas hermenêuticas, que abrigaram e potencializaram demandas e aspirações sociais.

Nesse contexto jurídico, em lugar de se identificar a procriação como origem quase exclusiva da filiação, o direito civil-constitucional defende que a socialidade é um critério importante para o estabelecimento da filiação, por meio da identificação do afeto entre pais e filhos. Em contraste à objetividade do modelo do Código Civil de 1916 e, em complemento com a socialidade, a metodologia civil-constitucional valoriza a afetividade como suporte fático para dar origem a relações jurídicas, tais como a união estável e a filiação.

Se o patrimonialismo marcou o Direito de Família do Código Civil de 1916, a metodologia civil-constitucional propõe um Direito de Família preocupado, preferencialmente, com a pessoa humana, relegando o patrimônio a instrumento para a sua realização. Aspira, portanto, a um personalismo.

Finalmente, pai e mãe, para a leitura civil-constitucional, devem ser titulares dos mesmos direitos e deveres no respeitante à família, consagrando a eliminação da inferioridade jurídica da mulher, já mitigada pelo Estatuto da Mulher Casada (Lei Federal nº 4.121, de 27 de agosto de 1962). No horizonte dessa paridade, delineia-se a igualdade de gênero.

A concepção de família formulada pelo Direito Civil-Constitucional encontra ressonância nas diretrizes que coordenam o Direito Civil, a partir do Código Civil de 2002: sistematicidade, 
operabilidade, eticidade e socialidade (MARTINS-COSTA; BRANCO, 2002, p. 131). Não só o Código, mas todo o Direito Civil, é lido como sistema aberto, instrumentalizado por conceitos jurídicos indeterminados e cláusulas gerais, cuja completude semântica e normativa depende da integração entre os documentos legais (como entre Código e Constituição) e da interpretação jurisprudencial (o que ressalta a importância das cláusulas gerais, como a da boa-fé objetiva). Nisso reside a diretriz da sistematicidade (MARTINS-COSTA; BRANCO, 2002, p. 118).

A operabilidade relaciona-se a duas propostas. A primeira corresponde a uma apuração da técnica, que viabiliza o tratamento de matérias complexas de maneira simples, tal como as normas pertinentes à prescrição e à decadência no Código Civil de 2002, se comparadas com a complexidade da regulação da matéria no Código de 1916 (MARTINS-COSTA; BRANCO, 2002, p. 109). A segunda proposta, da operabilidade, relaciona-se a uma busca de concretude; vale afirmar, o Direito Civil deve operar mediante o reconhecimento da pluralidade da vida social (MARTINS-COSTA; BRANCO, 2002, p. 123).

A diretriz da eticidade incide sobre o Direito Civil com o objetivo de proteger a pessoa, especialmente no tocante à sua relação com a comunidade (MARTINS-COSTA; BRANCO, 2002, p. 102-107). Por valorizar a relação com a comunidade, o Direito Civil é orientado e coordenado pela diretriz da socialidade, que visa a valorizar a solidariedade, razão por que o Código Civil trata da função social do contrato e da propriedade e por que ele se atrela à diretriz constitucional da solidariedade social (art. 3 , I e III, da Constituição da República) (MARTINS-COSTA; BRANCO, 2002, p. 144).

Diante dessas diretrizes codificadas do Direito Civil, após quase trinta anos de vigência da Constituição de 1988, torna-se interessante avaliar como têm sido recepcionadas pelo Supremo Tribunal Federal as formulações do Direito de Família almejadas pela hermenêutica civilconstitucional. Essa análise permite examinar como tais formulações têm sido concretizadas e, especialmente, como elas têm sido operadas no sistema de Direito de Família. Em outras palavras, é possível problematizar a tentativa do Supremo Tribunal Federal de acomodar as diretrizes do Direito Civil com a metodologia do Direito Civil-Constitucional no âmbito do Direito de Família, e avaliar sua consistência.

No caso específico da regulação jurídica da paternidade e da maternidade, o Supremo Tribunal Federal, recentemente, reconheceu a possibilidade jurídica da concomitância de diversos vínculos jurídicos de paternidade para um mesmo indivíduo, a denominada “pluriparentalidade”. Essa decisão tem elevada importância prática porque define novos contornos jurídicos da filiação e todos os seus efeitos (parentesco e sucessão, por exemplo). Ainda, os fundamentos dessa decisão se valem 
da metodologia civil-constitucional e, por isso, exemplificam a sua operabilidade para o Direito de Família e justificam sua análise teórica.

\section{PATERNIDADE E MATERNIDADE NO DIREITO CIVIL BRASILEIRO ANTERIOR À CONSTITUIÇÃO DE 1988}

A paternidade e a maternidade apresentam-se para o Direito Civil como uma forma de parentesco. O pátrio poder é o aspecto dinâmico dessa relação jurídica.

Em 1889, Lafayette Rodrigues Pereira, ao tratar da filiação, afirma:

Filiação é a relação que o facto da procriação estabelece entre duas pessoas, das quaes uma é nascida da outra.

Considerada com respeito ao filho, esta relação toma particularmente o nome de filiação; com respeito ao pae, o de paternidade; e com respeito á mãe, o de maternidade. (PEREIRA, 1889, p. 205) ${ }^{1}$.

Pontes de Miranda, sob a égide do Código Civil de 1916, define a filiação de maneira semelhante:

A relação que o fato da procriação estabelece entre duas pessoas, uma das quais nascida da outra, chama-se paternidade, ou maternidade, quando considerada com respeito ao pai, ou à mãe, e filiação, quando do filho para com qualquer dos genitores. (PONTES DE MIRANDA, 1947a, p. 36).

Para Pontes de Miranda, na linha do art. 332, do Código Civil de 1916, a adoção era parentesco civil, pois não resultava da consanguinidade (PONTES DE MIRANDA, 1947a, p. 21-22). Conforme ele definia, “[...] a adoção é ato solene pelo qual se cria entre o adotante e o adotado relação fictícia de paternidade e filiação.” (PONTES DE MIRANDA, 1947a, p. 177).

A partir desses conceitos, percebe-se que, sob o Código Civil de 1916, a paternidade, a maternidade e a filiação têm como origem o evento biológico da procriação (PONTES DE MIRANDA, 1947a, p. 177)². A adoção é compreendida como parentesco civil na medida em que mimetiza a relação jurídica entre pai e filho, razão pela qual é definida como ficção jurídica.

Ao condicionar o parentesco de filiação à procriação biológica, Pontes de Miranda estabelece interessante distinção entre família e parentesco, a partir da relação entre os cônjuges. Para o jurista, o cônjuge integra a família, mas não é parente do outro cônjuge, embora seja parente, por

\footnotetext{
${ }^{1} \mathrm{O}$ autor frisa que essa é a concepção filosófica de pátrio poder.

${ }^{2}$ No entanto, no regime do Código de 1916, estabelecia-se a distinção entre filhos. Os filhos legítimos eram aqueles cujos pais eram casados no momento da concepção ou do nascimento e os ilegítimos correspondiam àqueles cujos pais não atendiam a essa condição, tal como detalhado em nota de rodapé abaixo. Em virtude dessa diferença entre os filhos incidia a presunção Pater est quem nuptiae demonstrant, ou seja, presumia-se pai o marido da mãe (PONTES DE MIRANDA, 1947a, p. 41).
} 
afinidade, dos parentes consanguíneos desse outro cônjuge (PONTES DE MIRANDA, 1947a, p. 2223). Especificamente ao tratar da adoção, a concepção de família é complementada:

[...] e a família, como se pode verificar no direito romano e em tôdas as legislações, mais se funda em interdependência ou mesmo dependência espiritual do que em simples circunstâncias estranhas à vontade, como o nascimento. Entre as sociedades animais, por exemplo, nem sempre se encontra, nítido, o fato sociológico da associação familiar, embora o fato de geração natural seja o mesmo. A família é, pois, sociedade psicológica, a que a identidade de origem ancestral, se é o seu fundamento remoto, não representa, todavia, a sua condição essencial [...]” (PONTES DE MIRANDA, 1947a, p. 115).

A diferenciação entre família e parentesco sustentada por Pontes de Miranda fundamenta a possibilidade de existirem laços familiares, fundados no que ele denomina o "fato sociológico da associação familiar”, mas que não caracterizam relações jurídicas, sobretudo porque não implicam o fato jurídico correspondente ao parentesco.

A relevância dessa diferenciação reside na circunstância que, no curso do século XX, e principalmente para a hermenêutica civil-constitucional, percebe-se uma tentativa de atribuir efeitos jurídicos próprios a relações familiares que, na vigência do Código Civil de 1916, não tinham relevância para o Direito porque não podiam ser qualificadas como matrimônio (as uniões estáveis, por exemplo), ou como parentesco (a filiação socioafetiva, por exemplo). Essa diretiva civilconstitucional corresponde a uma aspiração por socialidade, contraposta, neste trabalho, à procriação como fonte preponderante do parentesco de filiação.

Assim, a primeira característica da paternidade e da maternidade na ordem jurídica anterior à Constituição de 1988 é serem apreendidas como relações jurídicas derivadas do fato biológico da procriação. Esse caráter estrutural e biológico da paternidade, da maternidade e da filiação desdobrase, no plano dinâmico, isto é, dos direitos e deveres inerentes a tais relações jurídicas, por meio do denominado pátrio poder. Da análise do pátrio poder, é possível extrair as demais características da paternidade e da maternidade na ordem anterior à Constituição de 1988: patrimonialismo e patriarcado.

Lafayette Rodrigues Pereira apresenta a definição de pátrio poder como o complexo de direitos sobre a pessoa e bens do filho confiados ao pai e à mãe e que tem por fundamento a incapacidade do filho menor e cujo exercício é indispensável para prover as suas necessidades:

No decurso da menoridade fallece ao ente humano a capacidade indispensavel para prover ás suas necessidades e reger sua pessoa e bens.

E' mister que alguem tome o infante sob sua protecção, que o alimente, que cultive os germens que lhe brotam no espirito; que, em uma palavra, o eduque, e zele e defenda seus interesses. 
Esta nobre missão á natureza confiou-a ao pai e á mãi. Presuppõe ella tanto em um como em outro, certos direitos sobre a pessoa e bens do filho. Estes direitos em seu complexo constituem o que se chama patrio poder. (PEREIRA, 1889, p. 203).

O civilista, contudo, critica a legislação por considerá-la afastada dessa concepção do pátrio poder por ele denominada de filosófica e que se destina ao cuidado dos filhos menores. Para ele, “[...] as leis civis têm desnaturado grosseiramente a instituição do patrio poder [...] convertendo-o, por uma singular inversão de seu fim, em pesado instrumento de prepotencia, do orgulho e da cobiça dos pais.” (PEREIRA, 1889, p. 204).

Ao tratar do pátrio poder regulamentado no direito positivo, o autor destaca que esse poder não é exercido pela mãe pois o direito brasileiro, “dominado pela tradição romana”, segundo a qual a mulher ocupava posição semelhante à da “filha-familias", não confere à mãe o pátrio poder (PEREIRA, 1889, p. 221).

Em termos de conteúdo, o pátrio poder confere ao pai o direito de educar o filho; tê-lo em sua guarda e companhia; corrigi-lo e castigá-lo moderadamente enquanto for menor; exigir serviços compatíveis com sua idade; conceder ou negar o consentimento para o casamento; nomear-lhe tutor em testamento; fazer testamento pelo filho e nomear a ele herdeiro para o caso de falecer dentro da idade pupilar; representá-lo para os atos da vida civil; apresentar queixas por crimes de que tenham sido vítimas, além de exigir que o filho lhe seja restituído de quem injustamente o tenha sob seu poder. Esses são os direitos que o pai tem sobre a pessoa do filho (PEREIRA, 1889, p. 207-209)4.

A definição de pátrio poder de Lafayette Rodrigues Pereira contém um elemento importante para ser contrastado com as formulações da metodologia civil-constitucional sobre a regulação da família pela ordem constitucional de 1988: a objetividade. O pátrio poder conceituado pelo civilista brasileiro é completamente dissociado de qualquer elemento subjetivo, de qualquer sentimento. Em seu conceito, não se menciona amor, afeto ou afeição. Nenhum sentimento é ligado ou desempenha qualquer função no exercício do pátrio poder.

Diferentemente da conceituação de Lafayette Rodrigues Pereira, Clovis Bevilaqua define o pátrio poder como conjunto de deveres:

O filho legitimo, emquanto menor, acha-se confiado á guarda de seus paes, que para bem cumprirem os deveres impostos pela necessidade de o educarem hão de ter sobre ele a

\footnotetext{
${ }^{3}$ Manteve-se entre aspas a expressão para se preservar a grafia utilizada pelo autor citado, como nas demais citações. Por isso, utilizou-se "filha-familias".

${ }^{4}$ Quanto aos bens do patrimônio do filho, antes do Código Civil de 1916, eles eram denominados pecúlio. Assim, o filho podia ser proprietário dos bens classificados como pecúlio profectício, pecúlio castrense, quase-castrense e pecúlio adventício. Sobre cada categoria de pecúlio incidia uma regulação diferente dos direitos e deveres cabíveis ao pai. Lafayette Rodrigues Pereira critica essa regulamentação, reputando-a desorganizada e fruto da sedimentação histórica do Direito Romano (PEREIRA, 1889, p. 213-218).
} 
auctoridade que todas as legislações têm reconhecido com maior ou menor amplitude. (BEVILAQUA, 1906, p. 105).

Embora o autor do projeto do Código Civil de 1916 não apresente nesse texto o pátrio poder como um complexo de direitos, a sua definição compartilha da mesma destacada característica daquela apresentada por Lafayette Rodrigues Pereira: é um poder desvinculado de sentimentos, desvinculado do afeto.

O conceito de pátrio poder apresentado por Pontes de Miranda, em seu Tratado de Direito de Família datado de 1947, também relaciona o seu exercício à formação dos filhos, de maneira objetiva:

O pátrio poder moderno é conjunto de direitos concedidos ao pai ou à própria mãe, a fim de que, graças a êles, possa melhor desempenhar a sua missão de guardar, defender e educar os filhos, formando-os e robustecendo-os para a sociedade e a vida. (PONTES DE MIRANDA, 1947a, p. 109-110).

O art. 384, do Código Civil de 1916, previa os poderes-deveres atribuídos aos pais relativamente aos seus filhos menores que, em síntese, correspondiam à direção de sua educação; a representá-los nos atos da vida civil até os dezesseis anos (assistindo-os após essa idade enquanto perdurasse a incapacidade civil pela menoridade) e a tê-los sob sua companhia e guarda. Ainda de acordo com o art. 385, do Código, em virtude do pátrio poder, o pai é o administrador dos bens pertencentes aos filhos menores. Esses poderes-deveres de representação para os atos da vida civil e de administrador dos bens revelavam a outra face da objetividade, que é a preocupação com o patrimônio familiar, o patrimonialismo.

Em síntese, a objetividade e o patrimonialismo inerentes ao pátrio poder presente nas definições de Lafayette Rodrigues Pereira e de Clovis Bevilaqua apresentam-se no conceito de Pontes de Miranda e na regulação do Código de 1916: é um poder desvinculado de sentimentos, desvinculado do afeto e cioso do patrimônio. Em contrapartida, as elaborações do direito civil-constitucional, no século XX, opõem a afetividade à objetividade e contrapõem o personalismo ao patrimonialismo.

Em relação a essas características, objetividade e patrimonialismo, deve-se ressaltar a posição da mulher no tocante ao exercício do pátrio poder, estabelecida pelo Código Civil de 1916. A partir do tratamento jurídico diferenciado para os filhos em conformidade com a sua origem ${ }^{5}$, notase, como terceira característica do pátrio poder, a posição de inferioridade jurídica reservada à mãe,

\footnotetext{
${ }^{5}$ Para além da definição do parentesco, a distinção jurídica entre filhos legítimos e ilegítimos tinha importantes efeitos, sobretudo na ordem sucessória, tal como previa o art. 1.605, do Código Civil de 1916. A impossibilidade de reconhecimento dos filhos incestuosos e dos filhos adulterinos foi revogada por meio do art. 126, da Constituição de 1937, que também revogou a norma do art. 1.605, § $1^{\circ}$, do Código de 1916, pois essa norma constitucional vedou a distinção legal entre filhos legítimos e legitimados (PONTES DE MIRANDA, 1947a, p. 75-86, 100-101).
} 
denotando um regime de patriarcado. A mãe exercia os poderes-deveres inerentes ao pátrio poder apenas de forma excepcional (art. 379 e 380, do Código Civil de 1916), como nos casos em que o pai fosse declarado ausente, interdito ou houvesse falecido ou, ainda, nas hipóteses de o filho ilegítimo não ter sido reconhecido pelo pai ou de filho adulterino ou incestuoso (PONTES DE MIRANDA, 1947a, p. 121-122) ${ }^{6}$.

Esse regramento do Código Civil de 1916 demonstra que o contorno jurídico da família se pautava por um desequilíbrio entre a paternidade e a maternidade. O pai exercia, preferencialmente, o pátrio poder, pelo qual dirigia a educação e representava os filhos menores em suas relações jurídicas. Ainda, o pai, na qualidade de marido, detinha a autoridade marital, reflexo da incapacidade civil da mulher. A mãe, nessa configuração, apenas podia exercer o pátrio poder em hipóteses excepcionais, associadas à impossibilidade do seu exercício pelo pai.

Em contraposição ao regime do patriarcado, o direito-civil constitucional busca, no século $\mathrm{XX}$, a igualdade jurídica entre homem e mulher, a igualdade de gênero, tanto no âmbito das relações matrimoniais, como no âmbito das relações com os filhos.

O contorno regulamentar da paternidade e da maternidade estabelecido pelo Código Civil de 1916 se caracterizava, portanto, pela procriação como fonte preponderante da relação jurídica de filiação; pela objetividade decorrente da irrelevância jurídica do afeto; pelo patrimonialismo correspondente ao objetivo prioritário de administração do patrimônio familiar e pelo patriarcado, referente à inferioridade jurídica da mulher no âmbito da relação matrimonial e no âmbito da relação entre pais e filhos ${ }^{7}$. Essas quatro características delimitam o sentido da paternidade e da maternidade segundo o regime do Código Civil de 1916.

No curso do século XX, em consonância com as transformações sociais e políticas da família, o Direito de Família brasileiro sofre mudanças ${ }^{8}$ cujo ápice se manifesta na Constituição da República de 1988. Relativamente à paternidade e à maternidade, tais alterações conformam a proposta de torná-las permeáveis à socialidade, no sentido de a procriação não ser origem preponderante da filiação; à afetividade, no sentido de o afeto ser suporte fático para formar relações jurídicas; ao personalismo, no sentido de pautar as relações familiares por valores existenciais,

\footnotetext{
${ }^{6}$ Ainda, sobre a inferioridade jurídica da mulher no regime do Código de 1916, cf. Pontes de Miranda (1947b, p. 48-50).

${ }^{7}$ O Código Civil de 1916 tratava a família a partir de perspectiva patriarcal e patrimonialista, tal como apontado por estudo tradicional (GOMES, 2003, p. 22-23).

${ }^{8}$ A família foi afetada pelo processo de urbanização, pela inserção da mulher no trabalho fora de casa e pela emancipação política e social da mulher. A família deixou de ser unidade de produção para ser espaço de ganhos e consumo, consequência da separação entre o local de trabalho e o local de convívio doméstico e familiar. Essas alterações sociais e políticas da família influenciaram as mudanças da sua regulação jurídica. Com farta bibliografia sobre o tema, cf. Oliveira e Muniz (1990, p. 10).
} 
distanciando-as das questões patrimoniais; à igualdade de gênero, no sentido de que haveria igualdade jurídica entre marido e mulher e entre pai e mãe na sua relação com os filhos e no desempenho das denominadas funções parentais.

A bibliografia especializada e a jurisprudência exemplificam as possibilidades de aplicação dessa proposta e, com base em recente precedente do Supremo Tribunal Federal, é possível problematizá-la.

\section{A CONSTITUIÇÃo DE 1988 E A REGULAÇÃO CIVIL-CONSTITUCIOINAL DA FAMÍLIA}

Com base na Constituição da República de 1988, especialistas em Direito Civil formularam a metodologia que reafirma a posição central dos princípios e normas constitucionais em relação ao Direito Civil e, por consequência, ao Direito de Família. Trata-se da metodologia civilconstitucional $^{9}$, a qual, no âmbito da regulação jurídica da paternidade e da maternidade, apresenta as seguintes formulações: socialidade, afetividade, personalismo e igualdade de gênero.

De acordo com essa metodologia, o ordenamento jurídico brasileiro é informado pelo princípio da dignidade da pessoa humana (art. $1^{\circ}$, III, da Constituição da República) e, no campo da regulação jurídica da família, essa valorização da pessoa ${ }^{10}$ implica a igualdade jurídica entre os indivíduos que compõem o núcleo familiar e a importância da afetividade como suporte fático para tutela jurídica de relações familiares.

Os arts. 226 e 227 da Constituição de 1988 consagram a igualdade entre homem e mulher, o reconhecimento jurídico das diversas formas de organização familiar (atribuindo proteção jurídica à família formada pelo casamento e às famílias que não se formam por esse vínculo, tais como as uniões estáveis, como as famílias monoparentais e como as famílias anaparentais), a igualdade entre os filhos e a possibilidade de dissolução do vínculo matrimonial pelo divórcio direto (LÔBO, 2011, p. 43).

Os autores que adotam a metodologia civil-constitucional qualificam esse modelo jurídico de família como eudemonista: o Estado não deve preservar apenas um modelo de família considerado regular, pois a família é vista como um instrumento para concretizar a felicidade dos indivíduos que formam o grupo familiar e ao Estado cumpre a função de regular juridicamente os meios dessa

\footnotetext{
${ }^{9}$ A base para a adoção dessa metodologia no Brasil é encontrada em Perlingieri (1997). No Brasil, pode-se exemplificar essa metodologia com: LÔBO, 1999; MORAES, 1999; RAMOS, 1996; TEPEDINO, 1999a.

10 A valorização da pessoa humana como centro do ordenamento jurídico tem o seguinte estudo precursor no Brasil: OLIVEIRA; MUNIZ, 1980. Posteriormente, ela recebe a nomenclatura de repersonalização do direito civil: FACHIN, 2000; TEPEDINO, 1999b. Especificamente quanto ao direito de família: LÔBO, 1989; TEPEDINO, 1999 c; LÔBO, 2002.
} 
realização pessoal, respeitando os diversos tipos de agrupamentos familiares escolhidos pelos indivíduos para atingirem a felicidade.

À medida que a família encontra proteção jurídica porque seria um caminho para a felicidade, proíbe-se ao Estado intervir na forma como os indivíduos se organizam para serem felizes. O Estado não pode ditar modos de vida e modos de organização familiar, não podendo intervir nas formas de expressão de vida individual e familiar, salvo nas situações em que tais formas de expressão causem danos a terceiros (OLIVEIRA; MUNIZ, 1990, p. 11; DIAS, 2011, p. 54-55; LÔBO, 2011, p. 18-20).

Ao se vislumbrar o fundamento da relevância jurídica da família no fato de ela ser um instrumento à serviço da felicidade de seus membros, tornando-a, em razão disso, imune à intervenção estatal e à imposição de modelos de organização familiar, percebe-se uma alteração importante na distinção entre parentesco e família, apontada por Pontes de Miranda.

De acordo com essa distinção, o parentesco é uma relação jurídica fundada, preponderantemente, no fato da procriação; a família, distintamente, é uma realidade caraterizada por laços sociais, mas que não produz, necessariamente, efeitos jurídicos. Ao se opor a essa diferença entre parentesco e família, a metodologia civil-constitucional destaca a função familiar, que seria atrelada à produção de felicidade (OLIVEIRA; MUNIZ, 1990, p. 19). Em virtude dessa função, as relações sociais que a cumprem são protegidas pelo Direito. Assim, por exemplo, a despeito da ausência da solenidade do matrimônio, a união estável pública e duradoura de pessoas com o objetivo de formar família produz efeitos jurídicos entre os conviventes (para fins sucessórios e no tocante ao regime de bens do casal).

Essa funcionalização jurídica de relações sociais inverte o argumento de Pontes de Miranda no tocante à filiação: mais importante que a procriação é a produção social de relações entre pais e filhos aptas a gerarem felicidade. E, sobre essas relações, o Estado não pode intervir, pois cada indivíduo e cada família tem direito a se organizar autonomamente em busca de sua felicidade ${ }^{11}$.

A socialidade corresponde a essa perspectiva segundo a qual a valorização jurídica de determinadas relações sociais depende de elas concretizarem finalidades correspondentes a valores almejados pelo direito positivo (como seria o valor “busca da felicidade”). Trata-se de diretriz do

\footnotetext{
${ }^{11}$ Embora o art. 227, § 7º, da Constituição da República de 1988 e o art. 1.513, do Código Civil de 2002, pautem-se pela norma da intervenção estatal mínima no âmbito das relações familiares, convém salientar, no tocante à paternidade e à maternidade, que a tutela jurídico-constitucional qualifica as crianças e os adolescentes como titulares de proteção especial em virtude de sua condição peculiar de pessoa em desenvolvimento e, por isso, considera-se justificável a previsão de mecanismo estatal de intervenção no âmbito familiar para a defesa dos filhos em relação aos pais que descumprem os deveres inerentes ao poder familiar, pois o art. 227, caput, da Constituição, prevê o dever coletivo de colocar crianças e adolescentes a salvo dos maus-tratos.
} 
Direito Civil contemporâneo, fundamental também para o reconhecimento da filiação em virtude do relacionamento afetivo entre pessoas.

Outra elaboração da metodologia civil-constitucional é a incidência da afetividade como suporte fático da proteção jurídica de certas relações fáticas. A partir de comportamentos concludentes manifestados publicamente, sustenta-se a possibilidade de se depreender o estado anímico de afeto entre as pessoas. Ao se inferir que determinadas relações jurídicas protegidas pelo Direito de Família correspondem a relações fáticas em que as pessoas, na realidade social, mantêm afeto entre si, conclui-se pela produção dessas relações jurídicas a partir da constatação daqueles comportamentos concludentes denotativos do estado subjetivo de afetividade, a despeito de aqueles comportamentos não serem acompanhados de solenidades exigíveis para tornar públicas e perfeitas determinadas relações jurídicas (CALDERÓN, 2017, p. 173-174).

Assim, por hipótese, duas pessoas que não celebraram a solenidade do matrimônio, não são casadas entre si, mas a convivência pública e duradoura e com o objetivo de formar família denota um estado subjetivo de afeto normalmente associado à relação social do casamento, o que viabiliza produzir a relação jurídica de união estável e seus efeitos jurídicos específicos correspondentes, tais como a comunhão de bens entre os companheiros e a qualificação deles como herdeiros necessários recíprocos.

De forma semelhante, o fato de uma pessoa usar o nome da família da outra, de uma delas ser tratada como filho da outra e de ser reconhecida pela comunidade como tal são comportamentos denotativos de um estado de afeto normalmente correspondente à relação social de filiação, viabilizando reconhecimento da relação jurídica de filiação socioafetiva, com efeitos jurídicos correspondentes, como o fato de o filho socioafetivo ser herdeiro necessário do pai ${ }^{12}$.

Se a civilística do século XIX não qualificava juridicamente o afeto eventualmente existente no exercício da paternidade e da maternidade, a civilística contemporânea visa a reconhecer essa afetividade como produtora de efeitos jurídicos relevantes e, sobretudo, preponderantes sobre disciplina patrimonial associada ao poder familiar. A atribuição de efeitos jurídicos ao afeto não é, contudo, imune a contradições e perplexidades, como será demonstrado com a análise do julgamento do recurso extraordinário $\mathrm{n}^{\circ}$ 898.060/SC.

\footnotetext{
${ }^{12}$ Essa filiação socioafetiva tem por fonte a noção de posse de estado de filho, que, no sistema do Código Civil de 1916, servia para provar a filiação legítima nos casos de falta ou de defeito no registro de nascimento (art. 349, desse Código). Haveria a posse de estado de filho para o suposto filho que usasse o nome do suposto pai (nominatio ou nomen), fosse mantido e educado pelo suposto pai, estabelecendo com ele laço social identificado com a filiação (tractatio) e que, por fim, gozasse a notoriedade social de filho do suposto pai (reputatio). Ver OLIVEIRA; MUNIZ, 1990, p. 46.
} 
Esses dois parâmetros da paternidade e da maternidade elaborados sob a metodologia civilconstitucional - a socialidade e a afetividade - conduzem ao terceiro, o personalismo. Se o pátrio poder, no Código Civil de 1916, correspondia precipuamente aos poderes de regência do pai sobre o patrimônio do filho, com a Constituição de 1988, ambiciona-se que a paternidade seja exercida com responsabilidade e em colaboração com a maternidade, justamente para alcançar a felicidade dos filhos.

A redação do art. 226, § $7^{\circ}$, da Constituição da República, é ilustrativa dessa orientação personalista ao estabelecer que o planejamento familiar tem como fundamento a dignidade da pessoa humana e a paternidade responsável. De um lado a dignidade da pessoa humana remete à influência destacada da doutrina social da Igreja Católica, fonte do personalismo (PERLINGIERI, 1997, p. 3536). De outro, o princípio da paternidade responsável condiciona a proteção jurídica do vínculo de filiação ao desempenho adequado das funções paternas e maternas. Em outras palavras, a paternidade e a maternidade, para encontrarem proteção jurídica, precisam ser exercidas no interesse dos filhos ${ }^{13}$.

Para a versão do personalismo aproveitada pelo Direito Civil-Constitucional, o pai e a mãe não devem ser meros gestores do patrimônio dos filhos menores, mas almeja-se que a mística familiar invada o Direito e que o afeto, surgido na convivência, opere no sistema jurídico para produzir direitos e deveres entre pais e filhos.

A quarta formulação da metodologia do Direito Civil-Constitucional relaciona-se a essa pretensão personalista. Para a civilística oitocentista, o pátrio poder era exercido, quase exclusivamente, pelo pai, focando a gestão patrimonial (o pai era o administrador dos bens componentes do patrimônio dos filhos menores e os representava nos atos da vida civil até os dezesseis anos). A mãe, que nem sequer tinha poderes sobre o patrimônio do casal em virtude da incapacidade relativa da mulher casada e da chefia do casal centrada no marido, exercia o pátrio poder em situações de desprestígio, quais sejam, naquelas de impossibilidade do pai (falecimento, interdição e ausência) e em relação aos filhos gravados por inferioridade jurídica, que não podiam ser reconhecidos pelo pai (os filhos adulterinos e incestuosos).

Diversamente, o art. 226, $\S 7^{\circ}$, da Constituição da República, traz uma diretiva de igualdade no exercício das funções parentais ao prever que o planejamento familiar é livre decisão do casal. A igualdade entre os gêneros estende-se ao casamento, pois, conforme o art. 226, § 5º da Constituição,

\footnotetext{
${ }^{13}$ Neste ponto, o princípio da paternidade responsável opera, sistematicamente, com o princípio do melhor interesse da criança e com o princípio da criança e do adolescente como pessoa em desenvolvimento (art. 227, § $3^{\circ}$, V, da Constituição da República). Sobre o equilíbrio entre o princípio da criança como pessoa em desenvolvimento e o princípio do melhor interesse da criança, cf. VAN BUEREN (1998, p. 50) e DOLINGER (2003, p. 89-93).
} 
homem e mulher exercem igualmente os direitos e deveres da sociedade conjugal. $\mathrm{O}$ art. 1.565 , $\S 2^{\circ}$, do Código Civil vigente, também estabelece que o planejamento familiar é uma livre decisão do casal e o art. 1.567, do mesmo Código, prevê que a sociedade conjugal é dirigida em igualdade pelo marido e pela mulher, mas acrescenta que eles devem adotar suas decisões com base no interesse do casal e dos filhos.

O patriarcado, a inferioridade jurídica da mulher contida no Código Civil de 1916, é substituído, na ordem civil-constitucional posterior a 1988, pela igualdade de gênero, de maneira que homem e mulher devem desempenhar o poder familiar com preocupação dedicada sobre o melhor interesse dos filhos e em colaboração igualitária. A associação entre esses dois elementos - o melhor interesse dos filhos e a colaboração igualitária - exige que pai e mãe exerçam os cuidados dos filhos com igual dedicação, ou seja, existe o igual dever jurídico de exercer as funções parentais inerentes ao poder familiar (art. 1.631, do Código Civil). Essa exigência reflete, portanto, a aspiração de eliminar a inferioridade jurídica da mulher em relação ao homem também no tocante aos filhos.

Pode-se afirmar que o Código Civil de 1916, ao dispor sobre o pátrio poder, preocupava-se, sobretudo, com a delimitação da autoridade paterna e com a regência do patrimônio familiar. Diferentemente, em lugar do pátrio poder e do patrimônio, o personalismo civil-constitucional foca o poder familiar na proteção da pessoa dos filhos desempenhada por meio de cuidados e de afetos, a denominada parentalidade ${ }^{14}$. Antes, no Código de 1916, o pátrio poder era patriarcal e patrimonialista; com o método civil-constitucional, visa-se a um poder familiar exercido com igualdade de gênero e personalista, preocupado, para além do patrimônio, com a adequação das funções parentais ao interesse dos filhos.

As quatro elaborações da metodologia civil-constitucional sobre a paternidade e a maternidade no direito de família brasileiro: em lugar da procriação, a socialidade; em lugar da objetividade, a afetividade; em lugar do patrimonialismo, o personalismo; em lugar do patriarcado, a igualdade de gênero.

No plano do direito positivo, a Constituição da República de 1988 porta os parâmetros normativos dessas elaborações, o que exemplifica, no plano abstrato do diálogo entre as fontes, a diretriz da sistematicidade aberta do Direito Civil contemporâneo. Passados quase trinta anos de sua promulgação, é premente confrontar essas elaborações com a prática jurisprudencial da Constituição,

\footnotetext{
${ }^{14} \mathrm{~A}$ autoridade parental corresponde ao poder jurídico dos pais voltado à proteção da pessoa e dos bens dos filhos. Já a parentalidade é um conceito originado na psicanálise e, posteriormente, transportado para a Sociologia e para o Direito. A parentalidade é um termo polissêmico, podendo designar, em geral, os cuidados que os pais, ou as pessoas que lhes fazem as vezes, devem dedicar aos seus filhos enquanto são crianças (FENOUILLET, 2014, p. 96-99).
} 
a fim de compreender até que ponto e como houve a sua implementação no plano concreto da regulação jurídica da família.

Essas formulações recentes do Direito de Família foram postas à prova no julgamento do Recurso Extraordinário $\mathrm{n}^{\circ}$ 898.060/SC pelo Supremo Tribunal Federal, que oferece a possibilidade de analisar criticamente a confluência das formas pelas quais o direito brasileiro regula o parentesco de filiação. Nesse julgamento, o Supremo fixou uma tese com repercussão geral ${ }^{15}$ para casos semelhantes.

\section{O SUPREMO TRIBUNAL FEDERAL E A FLUIDEZ DOS PARÂMETROS NORMATIVOS}

O caso sob julgamento no Recurso Extraordinário nº 898.060/SC é o seguinte ${ }^{16}$ : No registro civil de F. G. constava como pai I. G., que a reconheceu como filha porque acreditava ser seu pai, na medida em que era casado com sua mãe. Quando F. G. tinha dezesseis anos, tendo sido cuidada desde o nascimento por I. G., ela e I. G. descobriram que seu pai biológico era A. N. Após a descoberta, F. G. propôs ação investigatória de paternidade combinada com alimentos em face de A. N.

Após três exames genéticos de paternidade no curso do processo, restou provado que $\mathrm{A}$. N. era o genitor biológico de F. G. A sentença de primeiro grau julgou parcialmente procedente o pedido para: 1) declarar a paternidade de A. N. relativamente a F. G.; 2) determinar a retificação do registro de nascimento de F. G., excluindo-se os dados de I. G. e incluindo as informações do pai biológico, A. N.; 3) condenar A. N. ao pagamento de alimentos no valor de quatro salários mínimos em favor de F. G., desde a citação inicial até a conclusão do curso universitário, salvo em caso de interrupção de estudos.

Em face da sentença de primeiro grau, A. N. interpôs recurso de apelação e o Tribunal de Justiça de Santa Catarina o proveu, parcialmente, determinando que deveria prevalecer a paternidade socioafetiva de I. G. em relação a F. G., cabendo a esta unicamente o direito de ter reconhecido seu vínculo biológico com A. N. Em outras palavras, o acórdão de Santa Catarina determinou que F. G. era filha de I. G., embora tivesse sido gerada biologicamente por A. N. O fundamento decorreria do fato de F. G. ter estabelecido laço de afetividade com I. G., que não se formou com A. N.

\footnotetext{
${ }^{15}$ A repercussão geral corresponde a um requisito de admissibilidade do recurso extraordinário pelo Supremo Tribunal Federal. O julgamento de recurso extraordinário com repercussão geral reconhecida conduz à fixação de tese sobre a matéria julgada que deve ser observada por todo o Poder Judiciário em casos idênticos, bem como pela Administração Pública direta e indireta, no caso de o julgamento versar sobre serviços públicos prestados mediante concessão, permissão ou autorização.

${ }^{16} \mathrm{O}$ resumo do caso é extraído do acórdão que julgou os embargos infringentes, cf. SANTA CATARINA (2013).
} 
Posteriormente, F. G. interpôs embargos infringentes contra o acórdão que julgou a apelação, e o Grupo de Câmaras de Direito Civil do Tribunal de Justiça de Santa Catarina proveu os embargos para o fim de declarar a paternidade de A. N. em relação a F. G., restabelecendo a sentença de primeiro grau (exclusão dos dados paternos de I. G., inclusão dos dados de A. N. e condenação deste ao pagamento de alimentos em favor de F. G.).

Finalmente, foi interposto recurso extraordinário por A. N. com o objetivo de reformar a decisão do Tribunal de Justiça de Santa Catarina. O recorrente A. N. pretendia que o Supremo Tribunal Federal reformasse o acórdão de Santa Catarina, sob o fundamento de que haveria preponderância da paternidade socioafetiva sobre a biológica. Para tanto, A. N. sustentava que o tribunal catarinense havia violado o art. 226, $\S \S 4^{\circ}$ e $7^{\circ}$; o art. 227, caput e $\S 6^{\circ}$ e os arts. 229 e 230 , todos da Constituição da República. Para o Ministro Relator, caberia ao Supremo Tribunal Federal definir os efeitos jurídicos da descoberta da paternidade biológica nas situações em que existisse vínculo parental previamente reconhecido (BRASIL, 2016b, p. 6) ${ }^{17}$.

O recurso teve negado o seu provimento, ou seja, foi mantida a decisão do Tribunal de Justiça de Santa Catarina, e, para o fim de repercussão geral, estabelecendo-se parâmetro de julgamento para todo caso semelhante, fixou-se a seguinte tese: “A paternidade socioafetiva, declarada ou não em registro público, não impede o reconhecimento do vínculo de filiação concomitante baseado na origem biológica, com os efeitos jurídicos próprios” (BRASIL, 2016a). No caso concreto de F. G., embora houvesse laço de afetividade com I. G., foi desconstituída a relação de filiação que ela mantinha com ele, constituindo-a apenas com base no vínculo biológico estabelecido com $\mathrm{A}$. N.

Em dissonância com o resultado do caso concreto, a tese fixada para a finalidade de repercussão geral reconheceu que a afetividade pode caracterizar suporte fático para estabelecer a relação jurídica de filiação e, mais do que isso, a tese reconheceu a possibilidade da concomitância de relações de filiação para a mesma pessoa, ou seja, um indivíduo pode ter um pai em virtude da sua descendência biológica e pode ter outro pai em razão do laço de afeto que mantém com ele.

Para chegar a essa conclusão, o acórdão do Supremo Tribunal Federal recepciona a metodologia civil-constitucional e a diretriz da sistematicidade aberta ao indicar a Constituição como fonte do Direito de Família e ao se basear na premissa de que a Constituição de 1988 estabeleceu uma ruptura na regulamentação jurídica da família e da paternidade:

\footnotetext{
${ }^{17}$ Os dispositivos constitucionais citados tratam, em síntese, da pluralidade de formas de família (art. 226, § $4^{\circ}$ ), da paternidade responsável e do livre planejamento familiar (art. 226, § $7^{\circ}$ ), da prioridade absoluta da proteção à criança (art. 227, caput), da igualdade jurídica entre os filhos (art. 227, § 6º ), do dever de solidariedade entre pais e filhos (art. 229) e do dever de amparo familiar, social e estatal às pessoas idosas (art. 230).
} 
A Constituição de 1988 promoveu verdadeira revolução no campo do Direito de Família. Sabe-se que, sob a égide do Código Civil de 1916, a família era centrada no instituto do casamento, vínculo indissolúvel e objeto de especial proteção da lei. Era estabelecida a vetusta distinção entre filhos legítimos, legitimados e ilegítimos, baseando-se a filiação na rígida presunção de paternidade do marido (pater is est quem nuptiae demonstrant). $\mathrm{O}$ paradigma de então não era nem o afeto entre os familiares, nem sequer a origem biológica, mas sim a presunção baseada na centralidade do casamento.

$[\ldots]$

A partir da Carta de 1988, exige-se uma inversão de finalidades no campo civilístico: o regramento legal passa a ter de se adequar às peculiaridades e demandas dos variados relacionamentos interpessoais, em vez de impor uma moldura estática baseada no casamento entre homem e mulher. De forma percuciente, esclarece o Ministro Luiz Edson Fachin aquilo que denomina "concepção eudemonista da família”:

"Sob as relações de afeto, de solidariedade e de cooperação, proclama-se, com mais assento, a concepção eudemonista da família: não é mais o indivíduo que existe para a família e para o casamento, mas a família e o casamento existem para o seu desenvolvimento pessoal, em busca de sua aspiração à felicidade.” (BRASIL, 2016b, p. 7-13).

A infusão da normativa constitucional sobre o Direito de Família, pressuposto da metodologia civil-constitucional e da diretriz contemporânea da sistematicidade, é recepcionada pelo Supremo Tribunal Federal e é acompanhada das formulações que almejam uma nova regulação jurídica da família.

Após a análise de decisões da Suprema Corte dos Estados Unidos, o acórdão ressalta que o direito constitucional brasileiro também acolhe a proteção jurídica da busca da felicidade. De acordo com o voto do Ministro Relator, no âmbito do Direito de Família, essa proteção implica uma defesa do indivíduo contra as tentativas de o Estado estabelecer modelos pré-concebidos de família (BRASIL, 2016b, p. 11). Como exemplo do acolhimento dessa tese pelo Supremo Tribunal Federal, o voto do Ministro Relator cita o acórdão prolatado na ADI nº 4.277 (BRASIL, 2016b, p. 14), que, em maio de 2011, reconheceu como família a união contínua, pública e duradoura entre pessoas do mesmo sexo, segundo as mesmas regras e com as mesmas consequências da união estável mantida entre homem e mulher.

Para fundamentar especificamente a possibilidade de uma pessoa ter vários vínculos de paternidade conforme a origem de cada um deles (um vínculo de origem biológica e outro de caráter afetivo), o Ministro Relator se vale do princípio da busca da felicidade:

O sobreprincípio da dignidade humana, na sua dimensão de tutela da felicidade e realização
pessoal dos indivíduos a partir de suas próprias configurações existenciais, impõe o
reconhecimento, pelo ordenamento jurídico, de modelos familiares diversos da concepção
tradicional. O espectro legal deve acolher, nesse prisma, tanto vínculos de filiação
construídos pela relação afetiva entre os envolvidos, quanto aqueles originados da
ascendência biológica, por imposição do princípio da paternidade responsável, enunciado
expressamente no art. 226, $\S 7^{\circ}$, da Constituição. (BRASIL, 2016b, p. 17).

Ao se basear no princípio da dignidade humana, o Supremo Tribunal Federal acolhe a noção de família eudemonista, herdada do personalismo, para retratar a paternidade como um instrumento 
para a felicidade dos filhos, ainda que, para tanto, o filho tenha que ter mais de um pai. A paternidade deixa de ser retratada apenas como instrumento de gestão do patrimônio dos filhos.

Ademais, ao qualificar a paternidade como instrumento para felicidade dos filhos e da família, o Supremo Tribunal Federal recepciona a socialidade, pois condiciona a proteção jurídica do vínculo de filiação ao fato de esse vínculo gerar felicidade para pais e filhos. A filiação, assim, não é dependente apenas da procriação.

Percebe-se que o acórdão do Supremo Tribunal Federal se afasta daquela definição de parentesco e de família de Pontes de Miranda, de acordo com a qual o parentesco é relação jurídica com origem preponderante na procriação e a família, diversamente, corresponde a laços sociais que não são, necessariamente, protegidos pelo Direito.

O acórdão do Supremo Tribunal Federal, ao adotar a metodologia civil-constitucional, inverte tal raciocínio, pois, segundo o seu argumento, o parentesco e a família são protegidos pelo Direito na medida em que, independentemente do fato biológico da procriação, contribuem para a busca da felicidade. Portanto, a proteção jurídica da afetividade como suporte fático da relação jurídica de paternidade se justifica porque a filiação fundada no afeto atende ao suposto objetivo constitucional de viabilizar a busca da felicidade, o que patenteia o acolhimento da socialidade pelo Supremo Tribunal Federal.

Uma vez demonstrada a recepção da socialidade, a primeira crítica à decisão do Supremo Tribunal Federal relaciona-se ao seu percurso argumentativo. Isso porque, para explicar a proibição ao Estado de impor modelos familiares e modelos de paternidade, o Ministro Relator se vale de jurisprudência dos Estados Unidos, que não guarda qualquer relação com o Direito de Família brasileiro, e porque o Ministro Relator, para a mesma finalidade explicativa, se vale do suposto direito à busca da felicidade, que não encontra previsão expressa no direito positivo brasileiro.

Esse uso inadequado da jurisprudência estrangeira revela, inicialmente, um distanciamento do Supremo Tribunal Federal em relação às diretrizes da sistematicidade e da operabilidade, identificadas com a civilística contemporânea brasileira. Isso porque a desvinculação da jurisprudência estrangeira com o direito positivo brasileiro revela o descuido do Supremo Tribunal Federal em coordenar os documentos legais pátrios a partir de parâmetros neles previstos (a busca da felicidade, ausente da Constituição, não pode se conectar com as normas do Código Civil). Isso denota ausência de sistematicidade. A operabilidade da "busca da felicidade” também é inexistente, haja vista que ela é cláusula geral ausente do direito brasileiro.

Em lugar de uma injustificada análise de jurisprudência estrangeira, e em lugar de remissão a um direito cuja previsão expressa é inexistente, seria mais adequado fundamentar a proibição de o 
Estado impor modelos familiares em dois direitos fundamentais previstos no art. $5^{\circ}$, da Constituição - o direito à liberdade e o direito à privacidade. Tais normas positivadas permitem a proteção do indivíduo e do seu arranjo familiar contra pretensões do Estado e de terceiros de intervir sobre o seu modo de vida e sobre a sua organização familiar ${ }^{18}$.

Para a civilística contemporânea, como a família é qualificada como espaço privado voltado ao desenvolvimento da pessoa, esse espaço deve ser dotado da mais expressiva forma de proteção da privacidade, direito fundamental e direito da personalidade, oponível ao Estado e a terceiros:

Parece-nos exato o seguinte enquadramento teórico: o reconhecimento e garantia dos direitos do homem "nas formações sociais onde se desenvolve a sua personalidade" não encontram um limite pelo fato de a pessoa inserir-se na comunidade familiar, que constitui o local primeiro e mais imediato de expressão da personalidade. (OLIVEIRA; MUNIZ, 1990, p. $22)^{19}$.

Uma vez que a família é o centro para o qual se direcionam a proteção dos direitos fundamentais e da personalidade positivados, como é o direito à privacidade, torna-se desnecessária a menção ao direito à felicidade para fundamentar a tutela jurídica das formas de expressão familiar, pois ele não está previsto expressamente no direito positivo brasileiro.

Dessa maneira, o personalismo e a socialidade recepcionados pelo Supremo Tribunal Federal no acórdão analisado podem ser criticados pela ausência de parâmetro normativo seguro. Em outras palavras, independentemente da avaliação do resultado a que chegou o julgamento, é oportuno observar que o percurso hermenêutico empregado pelo Supremo Tribunal Federal para fundamentar o personalismo e a socialidade que viabilizam a denominada “pluriparentalidade” é destituído de parâmetros argumentativos sindicáveis, pois, a partir do princípio da dignidade da pessoa humana, faz derivar um suposto direito à felicidade, cuja previsão expressa é inexistente.

Para além de confrontar as diretrizes do Direito Civil da sistematicidade e da operabilidade, a insindicabilidade da fundamentação do Supremo Tribunal Federal é especialmente grave porque o caso examinado fixou tese com repercussão geral, apta a definir o resultado judicial de todos os outros casos semelhantes ${ }^{20}$.

\footnotetext{
${ }^{18}$ Conforme previsão do art. 5ํ. II, da Constituição de 1988, ninguém é obrigado a fazer ou a não fazer algo, salvo se houver determinação por lei. Trata-se do direito à liberdade, que impõe ao Estado a abstenção de exigir condutas dos indivíduos, salvo se houver ordem legal para tanto. Ainda, o art. 5 X, XI e XII, da Constituição, associado ao art. 21, do Código Civil, prevê a proteção da vida privada dos indivíduos, assegurando a sua inviolabilidade em face do Estado ou de outras pessoas.

${ }^{19} \mathrm{O}$ trecho citado argumentava a ilicitude de o marido violar a correspondência da mulher, mas serve plenamente para explicar a família como âmbito de privacidade.

${ }^{20}$ A importância do caso sob julgamento é ressaltada pelo Ministro Relator: "O caso ora em julgamento, seja qual for o resultado proclamado pelo colegiado, constituirá precedente essencial para a definição do estatuto constitucional das famílias, em especial a densificação conceitual de um dos componentes mais elementares dos direitos da personalidade: a filiação" (BRASIL, 2016b, p. 1).
} 
A recepção jurisprudencial do personalismo e da socialidade pelo Supremo Tribunal Federal é, portanto, objeto de crítica nesse caso porque ela serviu para produzir precedente com efeitos para toda a sociedade brasileira com base em argumentação fluida, imprecisa e desamparada de referência às normas expressas na legislação vigente, o que dificulta o debate sobre os fundamentos da decisão.

Se o personalismo e a socialidade são recepcionados pelo Supremo Tribunal Federal, a afetividade também o é, como prova o argumento do Ministro Relator:

\begin{abstract}
Mais que reproduzir a norma do art. 349, II, do diploma anterior em seu art. 1.605, o Código Civil de 2002 passou a preceituar, em seu art. 1.593, que o "parentesco é natural ou civil, conforme resulte de consanguinidade ou outra origem”. Desse modo, a própria lei passa a reconhecer que a consanguinidade concorre com outras formas de parentesco, dentre as quais certamente se inclui a afetividade. Um exemplo bastante comum na realidade pátria é a chamada “adoção à brasileira”, em que o sujeito se vale da presunção de veracidade do registro público para declarar a paternidade em relação a criança que sabe não possuir sua herança genética. Cuida-se de gesto nobre, decorrente da vontade de preencher um espaço afetivo que de outra forma restaria vago na vida do menor. [...] A filiação socioafetiva, porém, independe da realização de registro, bastando a consolidação do vínculo afetivo entre as partes ao longo do tempo, como sói ocorrer nos casos de posse do estado de filho. (BRASIL, 2016b, p. 16) ${ }^{21}$.
\end{abstract}

A referência à denominada “adoção à brasileira” para fundamentar a afetividade como suporte fático gerador da relação jurídica de filiação não é adequada porque o registro da paternidade de filho de outra pessoa corresponde ao tipo penal previsto no art. 242, do Código Penal. Assim, o voto do Ministro Relator se vale da descrição de conduta correspondente a crime para o fim de respaldar o afeto como suporte fático da filiação, o que é inadequado porque a defesa do afeto como produtor de relações jurídicas assenta-se na licitude dos comportamentos concludentes denotativos da presença do estado anímico de afeto comumente presente em determinadas relações jurídicas.

O outro parâmetro empregado no Supremo Tribunal Federal para justificar o afeto como suporte fático da filiação é mais adequado aos cânones da afetividade. O voto do Ministro Relator menciona a posse de estado de filho: a pessoa que usa o nome da família, que é tratada como filho e que goza do reconhecimento público da sua condição de filho, pode ser qualificado como filho (BRASIL, 2016, p. 15-16).

O que causa perplexidade, contudo, nesse reconhecimento da afetividade como produtora da relação jurídica de filiação é a completa ausência de problematização dos seus desdobramentos. Se o voto do Ministro Relator incide em tal omissão, o debate no Tribunal de Justiça de Santa Catarina traz importante reflexão sobre um desses desdobramentos.

\footnotetext{
${ }^{21}$ A despeito da melhor adequação desse argumento, deve-se ponderar que a posse de estado de filho, sob o regime do Código Civil de 1916, era instrumento para reconhecimento da filiação legítima em caso de falha ou falta de registro, como explicado em nota de rodapé anterior.
} 
O acórdão que julgou a apelação no Tribunal de Justiça de Santa Catarina ${ }^{22}$ se atém à afetividade justamente para respaldar o argumento do genitor biológico de que a paternidade afetiva estabelecida entre a autora F. G. e o pai afetivo I. G. não poderia ser desconstituída:

[...] a meu sentir está configurada, de forma incontestável, a paternidade sócio-afetiva, como resultado da convivência duradoura, do cultivo do afeto, da plena assistência, e de tudo aquilo que, numa visão atual - seja por parte da doutrina ou da jurisprudência de nossos Tribunais -, realmente se tem entendido constituir elemento a bem identificar uma relação parental entre pais e filhos.

Por isso, em que pese ter o vínculo de afetividade origem em registro cuja informação não corresponde à verdade biológica, ante a consolidação dos laços sentimentais/afetivos entre F. G. e I. G., o estado de filiação que esta última agora vindica em relação ao réu/apelante, não poderá ser reconhecido, simplesmente porque outro já se estabeleceu antes, com o pai registral, o qual não deverá ser desfeito. (SANTA CATARINA, 2011) ${ }^{23}$.

Esses argumentos acolhem a ideia de que o exercício da paternidade não se caracteriza pelo exercício do pátrio poder, focado na administração do patrimônio dos filhos, mas que o exercício da paternidade, tal como ressaltado a partir da perspectiva personalista, denominado atualmente como poder familiar, corresponde a uma função protetiva desempenhada por meio de cuidados e afetos, a denominada parentalidade.

Interessa observar como essa argumentação do Acórdão catarinense demonstra a necessidade de crítica ao percurso argumentativo do julgamento do Supremo Tribunal Federal. Ao se ater à dignidade da pessoa humana, ao suposto direito à busca de felicidade e à afetividade como suporte fático para relações jurídicas, o Supremo Tribunal Federal, para sustentar a possibilidade de uma pessoa ter mais de um pai, se valeu de referências a princípios de amplo conteúdo normativo (como é o caso da dignidade da pessoa humana), a direito que não está expressamente previsto no direito positivo (como o suposto direito à busca da felicidade), assim como à baliza hermenêutica que não está expressamente prevista no direito positivo para a finalidade pretendida (a afetividade não está expressamente prevista como fonte da relação jurídica de filiação).

Ora, ao se valer de percurso argumentativo tão normativamente indeterminado, torna-se viável contrapor a ele conclusões opostas baseadas nos mesmos cânones hermenêuticos. O Acórdão do Tribunal de Justiça de Santa Catarina tem especial relevância para demonstrar essa fragilidade argumentativa e hermenêutica, pois, ao se ater à afetividade como fonte de relações jurídicas (mesma

\footnotetext{
${ }^{22}$ É importante rememorar que, no Tribunal de Santa Catarina, os embargos infringentes foram interpostos por F. G. em face do acórdão que julgou procedente a apelação de A. N., tendo reformado a sentença de primeiro grau para julgar improcedente a ação de investigação de paternidade e o pedido de condenação de A. N. ao pagamento de alimentos, mantendo a sentença de primeiro grau apenas no tocante à declaração de vínculo biológico de F. G. relativamente a A. N. Cf. SANTA CATARINA (2011).

${ }^{23} \mathrm{O}$ voto vencido no julgamento dos embargos infringentes também se valeu da mesma linha argumentativa, a de que a presença da filiação afetiva consolidada impede o registro da filiação baseada no vínculo biológico. Cf. SANTA CATARINA (2013).
} 
premissa usada pelo Supremo Tribunal Federal), ele sustenta que a paternidade biológica não pode se sobrepor ou se igualar à paternidade afetiva (conclusão diversa do Tribunal Superior), especialmente porque o direito positivo protege o vínculo de filiação em conformidade com o objetivo a ele proposto, o de formar laços de afeto. Assim, na medida em que a autora F. G. tinha comprovados laços de afeto com o seu pai afetivo I. G., não haveria fundamento para desconstituir esse afeto protegido pelo Direito.

O confronto entre as conclusões opostas obtidas por meio dos argumentos do Supremo Tribunal Federal e do tribunal catarinense demonstra a fluidez normativa das suas premissas comuns. Essa fluidez patenteia como os argumentos do Supremo Tribunal Federal se distanciam das diretrizes da sistematicidade e da operabilidade que caracterizam a civilística contemporânea brasileira, pois tais diretrizes não visam a construir um Direito Civil pautado pela insegurança jurídica, em que premissas idênticas conduzam a conclusões e efeitos jurídicos opostos, com impossibilidade de razoável escolha entre eles (insindicabilidade).

Se a fundamentação civil-constitucional baseada nas formulações do personalismo, da socialidade e da afetividade é dotada de ambiguidade e de fluidez, tornando-a pouco apta para a produção de decisões sindicáveis, ela também pode conduzir à moralização do Direito, ou seja, à inclusão de opções morais do julgador no processo de decisão.

O julgamento da apelação pelo Tribunal catarinense é exemplificativo dessa moralização ao tratar da pretensão patrimonial da autora F. G. De acordo com o Acórdão, para além do laço afetivo estabelecido entre a autora F. G. e I. G., não deveria ser reconhecida a paternidade biológica de A. N. porque haveria indicação de que F. G. pretendia apenas obter vantagens patrimoniais decorrentes do registro da paternidade biológica:

[...] e considerando, igualmente, que declarou não ser seu objetivo ser desfeito o vínculo estabelecido com o pai registral ao deflagrar o processo, mas, sim, poder ser contemplada com os mesmos direitos dos outros filhos de seu genitor, denota-se que a ação possui intento eminentemente patrimonial.

Até porque, diante do quadro que se apresenta, somente benefícios de tal ordem poderiam resultar para a autora caso atendidos os pedidos por ela formulados quanto ao reconhecimento do estado de filiação, visto que a prestação de amor, carinho e afeto, não se pode impor àquele que, pela vontade própria, a recusa.

[...]

Deve, então, prevalecer a paternidade sócio-afetiva, visto que, além de integrante do processo de formação da personalidade de F. G., propulsora de sua interação como ser social, apresenta-se, ainda hoje, como aquela capaz de contribuir para o seu desenvolvimento como pessoa humana, de forma mais positiva, porquanto no que toca à paternidade fundada puramente no vínculo biológico, consoante se fez anotar a pouco [sic], esta apenas lhe resultaria em proveitos de ordem patrimonial. (SANTA CATARINA, 2011). 
Ao adotar a perspectiva personalista de paternidade, exercida por meio do poder familiar identificado com o cuidado e com o afeto, e não mais como instrumento de administração patrimonial (como o pátrio poder do Código de 1916), o acórdão catarinense, com evidente conotação moral, julga indevida a pretensão patrimonial de F. G. justamente porque essa pretensão seria oposta ao delineamento jurídico da paternidade como locus de afeto e cuidado. Não seria possível macular esse espaço místico da afetividade familiar com as questões terrenas afetas ao patrimônio.

Essa perspectiva desconsidera as necessidades materiais e como elas podem ser supridas por meio dos deveres de assistência material aos filhos, inerentes à maternidade e à paternidade, e a decisão do Supremo Tribunal Federal, com alcance de repercussão geral, pode significar uma solução para casos futuros, no tocante à colaboração patrimonial: a concomitância, no registro civil, da paternidade socioafetiva e da paternidade biológica, ambas com a produção de todos os seus efeitos, inclusive o de assistência material.

Entretanto, se, de um lado, o resultado do julgamento do Supremo Tribunal Federal pode trazer soluções, ressalta-se, de outro, o fato de que as mesmas premissas adotadas pelo Supremo Tribunal Federal (paternidade focada na afetividade em desprestígio ao patrimonialismo do Código Civil de 1916) podem conduzir a conclusões tão divergentes entre si, tal como expõe o julgamento do Tribunal de Santa Catarina e a conotação moral pejorativa que ele atribuiu à pretensão de assistência material da autora F. G. Essa disparidade decorrente da moralização da decisão judicial é mais um indicativo da necessidade de revisão crítica da aplicabilidade técnica, da operabilidade de parâmetros normativos indeterminados, como a afetividade.

A igualdade de gênero no exercício da paternidade e da maternidade não é expressamente enfrentada pela decisão do Supremo Tribunal Federal. Porém, ela é subjacente ao caso julgado porque ele decorreu da ausência de reconhecimento da paternidade de F. G. por A. N. quando do seu nascimento. Ao se confrontar os efeitos jurídicos que decorrem da ausência de reconhecimento da paternidade com a ausência de reconhecimento da maternidade no direito positivo brasileiro, percebese como essa igualdade não foi implementada.

Como efeito da ausência do reconhecimento da paternidade pelo genitor, tem-se a incidência das normas da Lei Federal $n^{\circ}$ 8.560/1992, com a instauração de procedimento oficioso de averiguação de paternidade, presidido pelo Poder Judiciário. Nesse procedimento, a mãe pode alegar a paternidade do suposto pai e ele é notificado para, em trinta dias, dizer se reconhece a paternidade alegada. Caso o suposto pai negue a paternidade ou fique em silêncio pelo prazo de trinta dias, a contar da notificação, os autos são remetidos ao Ministério Público para propositura da ação de investigação de paternidade, ressalvando que a criança também pode propor essa ação. 
No caso da mulher que pretende não ver reconhecida sua maternidade, a regulamentação jurídica é diversa. Primeiro, porque o direito brasileiro não permite o parto anônimo na forma prevista no art. 326, do Código Civil francês. Na França, a genitora pode exigir que sua identidade não conste do registro de nascimento, bem como que o filho biológico não possa requerer o registro da sua maternidade (LÔBO, 2011, p. 229-230) ${ }^{24}$.

No Brasil, sempre há o registro da maternidade da mãe que gesta biologicamente o filho, conferindo-se a ela o direito de, após o registro, entregar o filho para adoção, nos termos do art. 13, $\S 1^{\circ}$, e do art. 166, caput, $\S \S 1^{\circ}, 2^{\circ}$ e $\S 6^{\circ}$, todos da Lei Federal $n^{\circ} 8.069 / 1990$. Esses dispositivos preveem a necessidade de o consentimento com a adoção do filho ser manifestado pelos titulares do poder familiar (no caso, a mãe) em audiência judicial posterior ao nascimento da criança. Ainda, determinam que o consentimento da mãe deverá ser precedido, conforme o art. 166 , $\S 2^{\circ}$, de orientações e esclarecimentos da equipe interprofissional da Justiça da Infância e da Juventude (profissionais da assistência social, da psicologia, etc.) e, em caso de adoção, principalmente para explicar sobre a sua irrevogabilidade.

Ao se comparar os contornos jurídicos da ausência de reconhecimento da paternidade biológica com a pretensão de ausência de reconhecimento da maternidade biológica, exemplificamse as razões pelas quais a igualdade de gênero no exercício da paternidade e da maternidade não foi alcançada.

Primeiro, porque em inúmeros casos de ausência de reconhecimento voluntário da paternidade é possível que jamais se obtenha o registro da paternidade biológica, seja porque o pai é desconhecido, seja porque jamais se proponha a ação de investigação de paternidade contra ele (o Ministério Público pode não ter dados para tanto e a mãe pode se recusar a fornecê-los ou desconhecêlos).

Segundo, o caso julgado pelo Supremo Tribunal Federal exemplifica outro efeito prático da ausência do reconhecimento de paternidade, que corresponde à longa demora para o filho ou a filha obter a procedência do pedido da ação de investigação de paternidade, haja vista que o processo daquele caso tramitou por mais de dez anos ${ }^{25}$. Diversamente, no caso da genitora biológica, o direito

\footnotetext{
${ }^{24}$ Segundo esse autor, a Corte Europeia dos Direitos Humanos considerou válido o parto anônimo francês porque ele assegura ao filho o direito de conhecer suas origens. A redação do Código é a seguinte: “Artigo 326. Após o parto, a mãe pode requerer o segredo de sua admissão e a preservação de sua identidade.” Tradução livre de: "Article 326 Lors de l'accouchement, la mère peut demander que le secret de son admission et de son identité soit préservé.” (FRANÇA, 1804).

${ }^{25}$ Em novembro de 2013, no julgamento dos embargos infringentes, o Desembargador Relator registrou que o processo tramitava por período superior a dez anos. Cf. SANTA CATARINA (2013).
} 
positivo brasileiro não permite que ela deixe de ser registrada como mãe, pois ele não regulamenta o parto anônimo.

Ademais, em caso de a mãe pretender entregar a criança para adoção, ela será submetida a um rigoroso controle estatal sobre sua manifestação de vontade: será ouvida pela equipe interdisciplinar, ou seja, profissionais da psicologia e da assistência social e, em audiência judicial, presidida por juiz de Direito e com participação do Ministério Público, ela deverá ratificar sua manifestação de vontade de entregar a criança para adoção. Tal controle e constrangimento sobre a manifestação de vontade é inexistente no caso do homem que não reconhece espontaneamente sua paternidade em relação ao filho recém-nascido.

A desigualdade jurídica entre os gêneros implica, neste caso, um constrangimento estatal sobre a autonomia privada da mulher (aconselhamento por profissionais da psicologia e da assistência social, oitiva perante o juiz de Direito, por exemplo) inexistente para o homem (ele é apenas notificado da alegação de paternidade, no caso da averiguação oficiosa de paternidade).

Essa diferença no tratamento jurídico entre o homem que não pretende reconhecer a paternidade e a mulher que não pretende reconhecer a maternidade demonstra, em confronto com as diretrizes do Direito Civil, uma ausência de sistematicidade (por conta da desigualdade injustificada), de operabilidade (em virtude da desconsideração da vivência concreta), de eticidade (porque não protege adequadamente a mulher) e de socialidade (porque abstrai da realidade comunitária) na regulamentação jurídica da matéria.

A partir dessa discussão, percebe-se que, a despeito da tentativa de concretizar a igualdade de gênero, existe uma grave diferença na regulação jurídica do reconhecimento da paternidade e da maternidade no direito brasileiro.

\section{CONCLUSÃO}

A hermenêutica civil-constitucional, no âmbito do Direito de Família, pretende que as relações familiares sejam regulamentadas de maneira a concretizar as formulações da socialidade, da afetividade, do personalismo, da afetividade e da igualdade de gênero.

No plano da bibliografia especializada, essas elaborações confrontariam as características do Direito de Família regulamentado pelo Código Civil de 1916: procriação, objetividade, patrimonialismo e patriarcado.

Ao se confrontar tais elaborações com a forma pela qual elas foram recepcionadas pelo Supremo Tribunal Federal no julgamento do Recurso Extraordinário que fixou a tese sobre a 
“pluriparentalidade”, constata-se que a busca pela concretização delas é marcada por uma argumentação fluida, imprecisa e ambígua, pois as mesmas premissas adotadas pelo Supremo Tribunal Federal poderiam conduzir a conclusões opostas, tal como exemplificou a análise do julgamento antecedente do mesmo caso pelo Tribunal de Justiça de Santa Catarina.

Com o objetivo de evitar essa ambiguidade e com o uso das diretrizes do Direito Civil contemporâneo como ferramentas de análise (especialmente a sistematicidade e a operabilidade), conclui-se pela necessidade de se revisar criticamente a operabilidade de parâmetros normativos imprecisos, tais como a afetividade.

Ademais, ao tratar da aspiração à igualdade de gênero, o caso da "pluriparentalidade" julgado pelo Supremo Tribunal Federal permite demonstrar a inexistência de sistematicidade na regulamentação jurídica da conduta do homem que não pretende ser registrado como pai do filho que concebeu, e na regulamentação jurídica da pretensão da mulher que não quer ser registrada como mãe do filho que gerou. As duas situações, a do homem e a da mulher, recebem tratamento jurídico próprio e desigual.

Para além da ausência de sistematicidade, o desequilíbrio entre a situação do homem e a da mulher demonstra como ela sofre grave constrangimento estatal sobre o exercício de sua autonomia privada, denotando também distanciamento das diretrizes da operabilidade, da eticidade e da socialidade, que caracterizam o Código Civil e a civilística contemporânea.

\section{REFERÊNCIAS}

BEVILAQUA, Clovis. Em defeza do projecto de Codigo civil brazileiro. Rio de Janeiro: Liv. Francisco Alves, 1906. Disponível em: <https://goo.gl/67bA3F>. Acesso em: 20 jul. 2018.

BRASIL. Supremo Tribunal Federal Plenário, Recurso Extraordinário n. 898.060/SC. Relator: Min. Luiz Fux, Plenário, julgado em 29 set. 2016a. Diário de Justiça Eletrônico. Disponível em: $<$ https://goo.gl/b6gDg5>. Acesso em: 10 jul. 2018.

BRASIL. Supremo Tribunal Federal. Recurso Extraordinário n. 898.060/SC. Relator: Min. Luiz Fux, Plenário, julgado em 29 set. 2016b. Voto do Ministro Relator. Notícias STF. Disponível em: $<$ https://goo.gl/N1HJ7f>. Acesso em: 10 jul. 2018.

CALDERÓN, Ricardo. Princípio da afetividade no direito de família. 2. ed. Rio de Janeiro: Forense, 2017, p. 79-239.

DIAS, Maria Berenice. Manual de direito das famílias. 8. ed. rev. e atual. São Paulo: Editora Revista dos Tribunais, 2011, 688 p. 
DOLINGER, Jacob. Direito civil internacional. v.1 - A família no direito internacional privado. t. 2 - A criança no direito internacional. Rio de Janeiro: Renovar, 2003, p. 79-155.

FACHIN, Luiz Edson. Teoria crítica do direito civil. Rio de Janeiro: Renovar, 2000, p. 1-18.

FENOUILLET, Dominique. La parentalité, nouveau paradigme de la famille contemporaine? Archives de philosophie du droit, Paris, n. 57, p. 95-122, out. 2014.

FRANÇA. Code Civil (1804). Disponível em: <https://goo.gl/iVdSDq>. Acesso em: 1 ago. 2018.

GOMES, Orlando. Raízes históricas e sociológicas do código civil brasileiro. São Paulo: Martins Fontes, 2003, p. 1-48.

LÔBO, Paulo Luiz Netto. A repersonalização das relações de família. In: BITTAR, Carlos Alberto (Coord.). O Direito de família e a Constituição de 1988. São Paulo: Saraiva, 1989, p. 53-81.

LÔBO, Paulo Luiz Netto. Constitucionalização do direito civil. Revista de Informação Legislativa, Brasília, a. 36, n.141, p. 99-109, jan./ mar., 1999.

LÔBO, Paulo Luiz Netto. Entidades Familiares Constitucionalizadas: Para Além do Numerus Clausus. Revista Brasileira de Direito de Família, São Paulo, n. 12, p. 40-55, jan./fev./mar., 2002.

LÔBO, Paulo. Direito civil: famílias. 4.ed. São Paulo: Saraiva, 2011, 437 p.

MARTINS-COSTA, Judith; BRANCO, Gerson Luiz Carlos. O conteúdo do novo código em suas diretrizes fundamentais. In: MARTINS-COSTA, Judith; BRANCO, Gerson Luiz Carlos. Diretrizes teóricas do novo Código Civil brasileiro. São Paulo: Saraiva, 2002, p. 87-185.

MECANISMO ONLINE PARA REFERÊNCIAS (MORE). Versão 2.0. Florianópolis: UFSC Rexlab, 2013. Disponível em: <https://goo.gl/JqpEC0>. Acesso em: 27 nov. 2017.

MORAES, Maria Celina Bodin de. O Direito Civil Constitucional. In: CAMARGO, Margarida Maria Lacombe (Org.). 1988-1998: uma década de Constituição. Rio de Janeiro: Renovar, 1999, p. 115127.

OLIVEIRA, José Lamartine Corrêa de; MUNIZ, Francisco José Ferreira. O Estado de Direito e os Direitos da Personalidade. Revista dos Tribunais, São Paulo, n. 532, p. 11-23, fev. 1980.

OLIVEIRA, José Lamartine Corrêa de; MUNIZ, Francisco José Ferreira. Direito de Família: (Direito Matrimonial). Porto Alegre: Sergio Antonio Fabris Editor, 1990, 504 p.

PEREIRA, Lafayette Rodrigues. Direitos de família. Rio de Janeiro: Typ. da Tribuna Liberal, 1889, p. 203-224. Disponível em: <https://goo.gl/NRbzzL>. Acesso em: 20 jul. 2018.

PERLINGIERI, Pietro. Perfis do direito civil. Tradução Maria Cristina De Cicco. 3. ed., rev. e ampl. Rio de Janeiro: Renovar, 1997.

PONTES DE MIRANDA, Francisco Cavalcanti. Tratado de direito de família: volume III: Parentesco. 3. ed. São Paulo: Max Limonad, 1947a. 
PONTES DE MIRANDA, Francisco Cavalcanti. Tratado de direito de família: volume II: Direito Matrimonial (continuação). 3. ed. São Paulo: Max Limonad, 1947b, p. 48-51.

RAMOS, Carmem Lúcia Silveira. Algumas reflexões acerca da Constituição como lei fundamental do direito civil. Revista da Faculdade de Direito da UFPR. Curitiba, a. 29, n. 29, p. 147-172, 1996.

SANTA CATARINA. Tribunal de Justiça de Santa Catarina. Apelação Cível n. 2011.027498-4 e Agravo de Instrumento n. 2011.024143-5. Relator: Des. Luiz Fernando Boller, Quarta Câmara de Direito Civil, julgado em 22 set. 2011. Diário de Justiça Eletrônico. Disponível em: $<$ https://goo.gl/VFqSkg>. Acesso em: 9 set. 2018.

SANTA CATARINA. Tribunal de Justiça de Santa Catarina. Embargos Infringentes n. 2012.0385259. Relator: Des. Raulino Jacó Brüning, Grupo de Câmaras de Direito Civil, julgado em 13 nov. 2013. Diário de Justiça Eletrônico. Disponível em: <https://goo.gl/mff8ED>. Acesso em: 9 set. 2018.

TEPEDINO, Gustavo. A Disciplina Civil-constitucional das Relações Familiares. In: TEPEDINO, Gustavo. Temas de direito civil. Rio de Janeiro: Renovar, 1999c, p. 347-366.

TEPEDINO, Gustavo. A Tutela da Personalidade no Ordenamento Civil-Constitucional Brasileiro. In: TEPEDINO, Gustavo. Temas de direito civil. Rio de Janeiro: Renovar, 1999b, p. 23-54.

TEPEDINO, Gustavo. Premissas Metodológicas para a Constitucionalização do Direito Civil. In: TEPEDINO, Gustavo. Temas de direito civil. Rio de Janeiro: Renovar, 1999a, p. 1-22.

VAN BUEREN, Geraldine. The International Law on The Rights of the Child. The Hague: Kluwer Law International, 1998, 435 p. Universidade Federal do Paraná. Promotor de Justiça, membro do Ministério Público do Estado do Paraná. E-mail: rcavichioli@yahoo.com.br

José Antônio Peres Gediel Professor Titular de Direito Civil na Universidade Federal do Paraná. Doutor em Direito pelo Programa de Pós-Graduação em Direito da Universidade Federal do Paraná (PPGD/UFPR). Coordenador do Grupo de Pesquisa Biotec - Direito, biotecnologia e sociedade -, do Núcleo de Direitos Humanos e Desenvolvimento do PPGD/UFPR. Pós-Doutor pela Universidade de Montreal, Canadá. Pesquisador-visitante na Universidade de Buenos Aires, Argentina (2016). Pesquisador-visitante, Bolsista-Sênior Capes, na Universidade de Columbia, Nova Iorque, Estados Unidos da América (2017).E-mail: jagediel@gmail.com 